
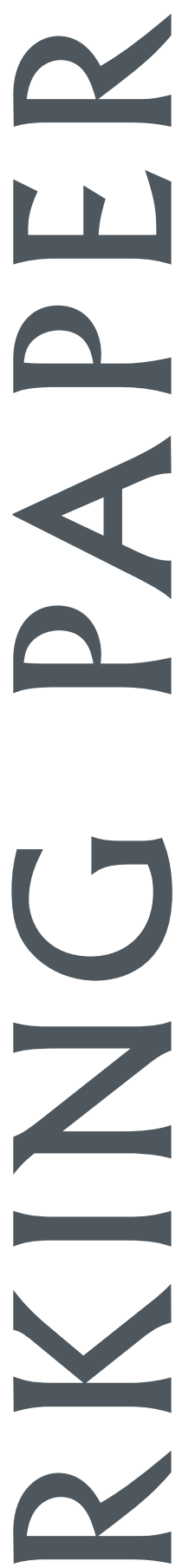

EAST-WEST CENTER 
The U.S. Congress established the East-West Center in 1960 to foster mutual understanding and cooperation among the governments and peoples of the Asia Pacific region including the United States. Funding for the Center comes from the U.S. government with additional support provided by private agencies, individuals, corporations, and Asian and Pacific governments.

East-West Center Working Papers are circulated for comment and to inform interested colleagues about work in progress at the Center.

For more information about the Center or to order publications, contact:

Publication Sales Office

East-West Center

1601 East-West Road

Honolulu, Hawaii 96848-1601

Telephone: 808-944-7145

Facsimile: 808-944-7376

Email: ewcbooks@EastWestCenter.org

Website: www.EastWestCenter.org 


\title{
Intellectual Property Rights in China: The Changing Political Economy of Chinese-American Interests
}

\author{
Sumner La Croix and Denise Eby Konan
}

Sumner La Croix is a Senior Fellow and Coordinator of China
Research at the East-West Center. He is also Professor and
Chair in the Department of Economics at the University of
Hawaii at Manoa.

His book, Japan's New Economy: Continuity and Change in the Twenty-First Century, was published by Oxford University Press in 2001. He has published numberous articles on the economic history and development of the Asia-Pacific region, with particular emphasis on intellectual property conflicts, institutional change and economic reform, the Asia-Pacific civil aviation industry, and foreign direct investment in China.

Denise Eby Konan is the Interim Assistant Vice Chancellor for Academic Affairs and an Associate Professor in the Department of Economics at the University of Hawaii at Manoa. Her research is focused on international trade policy. She has published numerous articles on trade reform issues involving foreign direct investment, intellectual property rights, the World Trade Organization, and regional economic integration.

Previously, she served as a trade policy advisor to the governments of Tunisia and Egypt, as well as the World Bank.

East-West Center Working Papers: Economics Series reports on research in progress. This paper has been peer-reviewed. The views expressed are those of the authors and not necessarily those of the Center. Please direct orders and requests to the East-West Center's Publication Sales Office. The price for Working Papers is $\$ 3.00$ each plus postage. For surface mail, add $\$ 3.00$ for the first title plus $\$ 0.75$ for each additional title or copy sent in the same shipment. For airmail within the U.S. and its territories, add $\$ 4.00$ for the first title plus $\$ 0.75$ for each additional title or copy in the same shipment. For airmail elsewhere, add $\$ 7.00$ for the first title plus $\$ 4.00$ for each additional title or copy in the same shipment. 


\begin{abstract}
We review the evolution of modern Chinese intellectual property right (IPR) laws and enforcement and explore economic and political forces involved in international conflicts over Chinese IPR protection. Our analysis considers why the U.S. and China moved from conflict to cooperation over intellectual property rights. Structural and institutional aspects of the political economy of IPRs within each country are considered, and data on Chinese-U.S. trade in intellectual property-intensive goods are examined. We conclude that although enforcement of IPRs within China continues to be relatively weak, Chinese IPR institutions are converging on those in the OECD nations.
\end{abstract}

Helpful comments were provided by Robert Ross, Keith Maskus, an anonymous referee, participants in the Chinese Academy of Social Science's International Conference on Transitional Relations on China, Japan, and the United States, in Beijing, China; the National Economic Forum at the University of Arizona; the Transpacific Conference on Business and Economics in Hilo, Hawaii; and the Western Economic Association International Annual Conference. We remain, of course, responsible for all errors, omissions, and fatal regressions. 


\section{INTRODUCTION}

Relations between China and the United States have become increasingly complicated over the last decade, with a large number of political and economic issues in dispute. Prominent among these issues have been the recurring disputes between the United States and China over Chinese protection of foreign intellectual property. Since 1991 four bilateral agreements between China and the United States have addressed Chinese protection of intellectual property rights (IPRS). While the agreements were accompanied in the mid-1990s by U.S. complaints over violations and subsequent bilateral tensions, the end of the millennium saw increased Chinese efforts to enforce foreign and domestic IPRS and less tension over the issue between the two governments.

Our focus in this paper is on the economic and political foundations of the ongoing disputes between the two governments as well as the rapid convergence of Chinese IPR law and enforcement to OECD standards. International politics have clearly played an important role in the disputes. For example, the 1996 dispute over IPRs was, at least in part, a spillover from the wider sphere of U.S.-China relations, in particular the contention over Taiwan policies and the 1996 visit of Taiwan's president to the United States. Domestic politics have played a role in the disputes, with the mid-1990s leadership transition in China (from Deng Xiaoping to Jiang Zemin) and the 1996 U.S. presidential election increasing the need for politicians in both countries to become less flexible in their public stances, thereby further extending IPR negotiations and deepening tensions. Economic considerations have also played a fundamental role in these disputes. As a net exporter of intellectual property as well as IPR-intensive products, the United States has incentives to pressure China to upgrade IPR laws and enforcement, while China, a net importer of intellectual property and IPR-intensive goods, has incentives to 
resist. ${ }^{1}$ Relations between the two parties are tempered by the limited capacity of China's legal system and society to change rapidly in response to both domestic and foreign pressures. We argue that China's desire to join the World Trade Organization (WTO) fundamentally changed the nature of the game due to the WTO's strong minimum standards for IPR laws and the veto held by the United States and the European Union over Chinese ascension to WTO membership.

\section{IPRS IN CHINA AND RECURRING DISPUTES WITH THE UNITED STATES}

Prior to its enactment of modern IPR laws in the 1980s, China had three decades of checkered experiences with intellectual property institutions borrowed from the USSR. The October 1949 founding of the PRC was followed in August 1950 by the promulgation of the central government's Provisional Regulations on the Protection of Inventions Rights and Patent Rights. ${ }^{2}$ Inventors were awarded a "certificate of invention," entitling them to recognition and monetary rewards tied to cost savings from their inventions. The state retained the right to exploit the invention. Procedures for registering trademarks were also promulgated in 1950, although few marks were registered. In 1963 new trademark regulations were issued requiring trademark registration, with the intent being to improve product quality. Publishing regulations provided authors with rewards based on the nature of the work, quantity and quality of Chinese characters, and number of copies printed.

The Cultural Revolution (1965-1976) led to the complete breakdown of this system. The professional activities of scientists, artists and writers were severely restricted, and regulations governing compensation of authors and inventors were

\footnotetext{
${ }^{1}$ See Gruen and Prior (1996).

${ }^{2}$ The following two paragraphs are based on Alford (1995, ch. 4).
} 
generally ignored or repealed. Restoration began only in 1977 when the "Four Modernizations" program focused on strengthening China's capabilities in technology and science. After 1978, under Deng Xiaoping, China passed patent, copyright, and trademark laws that meet most international standards; established major organizations for training officials, registering rights, and adjudicating disputes; and made great strides in enforcing its new IPR laws. The rapid progress was accompanied from the start by external pressure from the United States and the European Union. ${ }^{3}$ China's opening to foreign trade in the early 1970s trigged concerns by foreign firms selling products in China that Chinese law did not protect IPRs attached to these products. The 1979 Agreement on Trade Relations between the United States and China specified that China would adopt international IPR standards to protect intellectual property embodied in traded goods from the United States.

Since 1980, China has made extensive progress in joining international IPR conventions, passing domestic IPR laws, and establishing registration, enforcement, and training procedures. We briefly review major accomplishments. ${ }^{4}$

- International Conventions. Beijing has joined virtually all major international IPR conventions, beginning with the World Intellectual Property Organization in 1980; the Paris Convention in 1984; the Madrid Protocol and the Washington Convention in 1989; the Berne Convention and the Universal Copyright Convention in 1992; the Geneva Phonograms Convention in 1993; and the Patent Cooperation Treaty in 1994. Beijing also adheres to the Budapest Treaty on Deposit of Microorganisms; the Nice Agreement on Marks; the Strasbourg Agreement on international patent classification; the Locarno Agreement on industrial design classification; the Revised International Convention for the Protection of New Varieties of Plants; and the 2000 Patent Law Treaty.

- Domestic Laws. Beijing got off to a fast start with passage of its trademark law in 1982 and its patent law in 1984 but was slower to adopt other basic statutes. Its

\footnotetext{
${ }^{3}$ US and British pressure on China to establish IPRs has a long history, beginning after the Boxer Rebellion in 1900. The Mackay Treaty of 1902 with Great Britain and China's 1903 treaty with the United States both allowed for protection of foreign trademarks (Alford, 1995, ch. 3).

${ }^{4}$ See Yu (1994), Yeh (1996), and Pun (1996) for more extensive discussions.
} 
copyright law was delayed until 1990 and regulations protecting computer software were not enacted until 1991. Decisions of the National People's Congress Standing Committee in 1993 and 1994 have strengthened penalties against counterfeiting and infringing on copyrights. China enacted new copyright and trademark laws on October 27, 2001 to bring them into conformity with the TRIPS Agreement. An amended Patent Law was approved by the People's Congress in August 2000 and came into effect in July 2001. China issued new regulations for protecting plant varieties and layout designs of integrated circuits, effective October 1, 1997. Trade secrets are protected under Article 10 of the Chinese Unfair Competition Law.

- Special IPR Courts. China has established special IPR courts in 5 provinces and cities: Hainan, Guangdong, Fujian, Beijing, and Shanghai (Kolton, 1996).

Specialized courts were set up to ensure that judges well versed in complex IPR law hear these cases. The new Chinese courts have awarded monetary damages to major American corporations, such as Prentice Hall, Harcourt Brace, and World Disney as remedies for copyright violations. Foreign firms have, however, complained that Chinese courts have few mechanisms for enforcing their orders. ${ }^{5}$ Foreign attention has also been focused on Article 62(3) of TRIPS, which requires that all final administrative decisions with respect to IPRs be subject to review, by a judicial or quasi-judicial authority. Currently, most administrative decisions in China are final. China's courts also do not allow the award of damages in IPR infringement cases in which the infringer was unaware that infringement was taking place. This conflicts with Article 45(2) of TRIPS, which allows for damages even if the infringer was unaware that the infringing activity was against the law.

- IPR Databases. Monetary aid and personnel training from the German government helped the Chinese government to establish electronic data bases for patents in 1995.

- Training Programs. Several major universities, e.g., Beijing University, the People's University, and Wuhan University, have established IPR training programs for judges, lawyers, government IPR officials, and businessmen.

- Software Title Verification Office. Opened in Beijing in May 1997, this office is intended to act as a liaison between Chinese CD-ROM manufacturers and American software publishers. The Office is supposed to verify the legitimacy of a software order at a Chinese factory by verifying a contract with the software's original publisher.

- Internet IPRs. China has been slow to pass legislation regulating internet copyright and trademark issues. However, in 2000 the Beijing Supreme Court issued a "Guide Opinion on the Trial of Civil Cases Related to IP Rights Caused by the Registration \& Use of Domain Names," which acknowledges that registering and using wellknown trademarks as domain names constitutes unfair competition. Also, in December 2000, China's Supreme People's Court issued interpretations of China's

\footnotetext{
${ }^{5}$ See Seth Faison, "Pirates Show their Colors: Chinese Firms Start to Defy Courts, International Herald Tribune, May 18, 1995, p. 17.
} 
IPR laws with respect to their applicability to internet copyright disputes. The October 2001 revision of China's copyright law incorporated numerous new provisions governing on-line copyright protection.

Despite these accomplishments, there have been recurring disputes over IPRs between the United States and China. The two governments initiated ongoing "IPR consultations" in 1986. In May 1991, the U.S. Government opened a Special 301 investigation of IPR protection in China. Six rounds of bilateral negotiations led to a Memorandum of Understanding in January 1992. China agreed to upgrade its patent, copyright, trademark, and trade secret laws and to join major international conventions.

Since 1994, U.S. complaints have generally focused on enforcement of IPRs rather than changes in their content. In 1994, the USTR complained to the Chinese Government that Chinese firms were violating U.S. copyrights on a variety of goods, including computer software, CDs, LDs, and audiocassettes. Chinese media laws restricted the lawful distribution of imported CDs and cassette tapes, yet a large majority of the 75 million CDs produced in China contained copyrighted songs used without permission of their owners. Outdoor markets near major universities, such as in the Zhongguancun district near Beijing University, openly sold pirated software programs. The Computer Software Association reported that China purchased just \$1 of software per desktop computer, the lowest rate in the world. ${ }^{6}$

The Chinese government responded to U.S. complaints by shutting down several CD factories producing pirated discs; the United States government responded by threatening to impose trade sanctions beginning February 26, 1995 unless additional enforcement was undertaken. Formal U.S. sanctions would take the form of retaliatory tariffs on Chinese exports, such as cellular telephones, sporting goods, and plastic items.

\footnotetext{
${ }^{6}$ Reuters, Jan. 20, 1995.
} 
More importantly, the United States would continue to veto China's application to become a member of the World Trade Organization. China quickly responded by announcing that it would retaliate by imposing tariffs on selected U.S. goods, such as alcohol, cigarettes, video games, and compact discs; suspending joint venture talks with U.S. automobile companies; and possibly purchasing more aircraft from Europe's Airbus Industrie Consortium rather than the U.S.'s Boeing Company.

The conflict was resolved when China agreed to a new bilateral copyright agreement just hours after the U.S. deadline expired. The detailed 30-page text contained numerous important features.

- Export of infringing products prohibited;

- Factories producing infringing CDs to be closed;

- A title verification system to be established to prevent use or sale of audio visual works without the consent of the U.S. copyright owner;

- IPR working groups to be established at the central, provincial, and local levels to coordinate enforcement efforts and to draft and implement regulations and legislation;

- Focused enforcement efforts to be established for IPRs in audio visual works, computer programs, and publications;

- National treatment for civil filing fees and expeditious handling of IPR cases involving foreigners to be implemented; foreigners will have the right to initiate investigations of infringement of their rights, to petition relevant authorities for enforcement action, and to collect and submit evidence towards their complaints;

- No quotas to be established on U.S. audio visual products;

- Record companies to be allowed to market their entire catalog of works subject to censorship concerns;

- All IPR laws, regulations, interpretations, rules, and decrees to be compiled and published by September 1, 1995; 
- U.S. IPR-related companies to be allowed to enter into joint ventures for the production and reproduction of their works in China. Initial ventures limited to Shanghai and Guangzhou and expanded to 11 other cities by $2000 .^{7}$

China implemented parts of this agreement by carrying out thousands of raids on retail outlets selling pirated products, upgrading enforcement efforts, and closing seven infringing CD factories. Increased judicial protection of IPRs was highlighted by the Walt Disney Co.'s court judgment against several Chinese companies producing works showing unlicensed Disney characters. Despite these positive measures, approximately 30-45 licensed and unlicensed factories continued to produce infringing CDs; village "viewing rooms" showing pirated LDs thrived; and most computer software sold in retail stores was illegally copied. ${ }^{8}$ The International Federation of the Phonographic Industry claimed that 36 million of the 40 million CDs produced in China during 1995 used copyrighted songs without permission. Fines for violations were also considered inadequate in some prominent cases. For example, a court imposed a fine of only $\$ 2,500$ for pirating 200,000 copies of Microsoft's DOS operating system. ${ }^{9}$

In early 1996 the United States government demanded that the Chinese government close the infringing CD factories, tighten customs controls on exports of pirated goods, and provide greater market access to copyrighted U.S. music, films, and software. The United States targeted $\$ 3$ billion in Chinese clothing and electronic products for tariffs, while China targeted American movies, TV programs, and CDs for tariffs and announced the suspension of joint venture talks with American pharmaceutical and chemical firms.

\footnotetext{
${ }^{7}$ China subsequently signed a similar agreement with the EU. The EU did not conduct formal investigations of Chinese enforcement of IPRs during the 1990s, but did communicate its intent not to allow China into the WTO until it protects intellectual property according to the TRIPS standards.

${ }^{8}$ In the early 1990s China started to pay royalties to international music publishers when songs were played on the radio, on a concert stage, in television commercials, or in a karaoke bar. Payments to international music publishers totaled only US\$400,000 in 1994.

${ }^{9}$ See Far Eastern Economic Review, May 19, 1994, p. 55.
} 
The dispute was settled on June 17, 1996 when China agreed to close the infringing $\mathrm{CD}$ factories and to increase its enforcement efforts against piracy. China increased its enforcement efforts in the months prior to the June agreement and has continued stronger enforcement efforts through 2001. Most of the infringing CD factories have been closed, and stamps used to produce infringing CDs destroyed. Several wholesale centers in Guangdong Province selling pirated CDs have been shut down. Efforts have been made to close "LD viewing rooms." Increased enforcement efforts by Chinese customs agents have stopped the export of tens of thousands of infringing CDs, LDs, and Video Compact Discs (VCDs) to neighboring economies. Chinese customs officials have participated in several U.S.-organized IPR training sessions.

The increased Chinese IPR enforcement has had some unintended consequences. Chinese crackdowns on piracy of VCDs pushed counterfeiters "offshore" to Macau and Hong Kong beginning in 1997. Macau had no copyright law and the International Federation of Phonographic Industries estimated that each day 500,000 VCDs were smuggled from Macau into China. The boom in pirated VCDs has ignited a huge demand in China for VCD players, with 57 million produced between 1994 and $1999 .{ }^{10}$ Chinese officials concede that they have been unable to control VCD piracy, despite having success in controlling piracy of some other goods. While American trade officials are aware of these problems, they have been reluctant to pressure China more heavily in light of its increased IPR enforcement efforts.

\section{THE COSTS AND BENEFITS OF STRENGTHENING IPRS IN CHINA}

\footnotetext{
${ }^{10}$ See Seth Faison, "China Turns Blind Eye to Pirated Disks," New York Times, March 28, 1998, D1, D2 and Zhongguo Dianzi Bao (China Electronic News), March 15, 2000. Sales of Chinese VCD players have created a powerful domestic interest group, VCD manufacturers, that clearly benefits from VCD piracy.
} 
In this section we briefly review the potential costs and benefits to China of strengthening their intellectual property regime. Though necessarily speculative, this discussion is informed by a growing literature on the relationship between IPRs and economic development. ${ }^{11}$ The interested reader is referred to more extensive literature surveys (Besen and Raskind 1991, Evenson and Westphal 1997, Maskus and Konan 1994, Primo Braga 1996, and Maskus 2000).

Innovation and creative works may benefit China by adding to the variety of products available, improving the quality and attributes of existing products, and enriching culture. Innovative and creative works differ from most other goods in that they are nonrivalrous, i.e., the inventors may find it prohibitively costly to exclude an imitator from reproducing their creative works. Unless property rights in intellectual innovations are established and their enforcement is facilitated by the rule of law, market participants will have little incentive to compensate creators once the innovation becomes public knowledge. By limiting market access, IPR owners are able to charge a monopoly price above the production cost. This price should be sufficiently high to compensate the inventor for production and creative costs, provide a reasonable rate of profit, and offset the risk burden associated with the creative process. Yet by allowing IPR owners to set monopoly prices for the duration of the intellectual property right, ex post efficiency losses result as the IPR restricts availability and increases cost of using existing creative products. Thus a tradeoff exists. Too weak IPR protection discourages creative activity

\footnotetext{
${ }^{11}$ Gould and Gruben (1996) found no relationship between stronger patent laws and economic growth but that a strong relationship between patent strength interacted with a measure of trade liberalization and economic growth. Park and Ginarte (1997) found no relationship between stronger patent laws and economic growth but that strong IPR protection increases physical investment and R\&D spending, two basic determinants of economic growth.
} 
and dampens variety of products available while too strong protection provides excessive market power.

As China becomes more integrated in the world economy, intellectual innovations spill over its borders more readily. A large number of studies have isolated numerous determinates of the gains or losses from a country's adoption of stronger IPRs in a global context. ${ }^{12}$ They include the country's potential to attract foreign investment; whether the country's firms are capable of developing patentable products and processes; the ability of the country's R\&D sector to respond to the new incentives; and the popularity of domestic music, films, art, computer programs, and other literary works. Will China gain from adopting stronger IPRs and enforcing foreign and domestic intellectual property rights more closely? The answer depends on the strength and interaction of several important effects.

Rent Transfer Effect

As a net importer of innovation and technology, China has traditionally maintained low IPR protection to encourage low-cost imitation. Chinese firms regularly counterfeit foreign copyrighted movies, music, and computer software. The technology for high-quality copying is readily available. For example, CD replicators cost only $\$ 2.5$ million each in 1997 (down from \$30 million in 1987) and are "small, portable, and easy to use."13 Manufacturers of CD replicators in the Netherlands, Germany, and Sweden regularly soldl replicators to Chinese firms in the mid-1990s without inquiring whether they were using them to produce CDs containing pirated music. Unauthorized use of

\footnotetext{
${ }^{12}$ See Taylor (1994), Helpman (1993), Maskus (1990), Grossman and Helpman (1991, 1994), Diwan and Rodrik (1991), Deardorff (1992), Kawaura and La Croix (1995), La Croix and Kawaura (1996), Maskus and Konan (1994), and Chin and Grossman (1991).

${ }^{13}$ See Robert S. Greenberger and Craig R. Smith, "CD Piracy Flourishes in China, and West Supplies Equipment,” Wall Street Journal, April 24, 1997, pp. A1, A13.
} 
prominent foreign trademarks on goods such as clothing, watches, and handbags is also widespread. The temptation to infringe on IPRs is fueled by the large gap between the market price of the legitimate product and the cost of production of "close" imitations. The ability to imitate technology in labor-intensive industries enables many Chinese firms to compete effectively in global markets. The percentage of GDP as trade (imports plus exports) has increased from $9.8 \%$ in 1978 to $34.42 \%$ in 1999 (China Statistical Yearbook, 1999, pp. 55, 577-78).

The strengthening of IPR protection essentially raises China's cost of technology acquisition as local producers are forced to either pay royalties to Western IPR owners or to exit the market. This induces increases in product prices and a transfer of rents and royalties from Chinese consumers and producers to foreign IPR owners (Chin and Grossman 1988, Maskus 1990, Deardorff 1990, Helpman 1993). From China’s perspective, tighter IPRs imply deterioration in its terms of trade. Thus, it is unsurprising to observe the Chinese government trying to "jawbone" foreign patent holders proposing to collect fees deemed "excessive" by the Chinese government. Recent protests by the Chinese government against a plan by six foreign DVD developers to collect additional royalties from China's DVD equipment manufacturers falls into this category. ${ }^{14}$

\section{Innovation effect}

Strengthening IPR protection could have a beneficial effect on innovation and R\&D in China under some circumstances. Stimulating spending on research and development in China is particularly important due to its low level and concentration in public institutions during the Maoist era (1949-1977). Wu (1995) finds that China's government has undertaken extensive reform of its state R\&D institutions since 1978 and

\footnotetext{
${ }^{14}$ See story in Zhonghua Gongshang Shibao (China Business Times), November 14, 2000.
} 
has encouraged the development of R\&D in the new private industrial sector.

Nonetheless, in 1994 China expended just $0.5 \%$ of its GNP on R\&D, well below the developing country average of $0.64 \%$ and significantly less than the developed country average of $2.92 \%(\mathrm{Wu}, 1995)$. China's R\&D as a percentage of GNP increased to .71\% by 1998, an increase which may be partially due to stronger IPR institutions as well as the changing structure of the economy (China Statistical Yearbook, 1999, pp. 55, 675).

While a weak IPR regime may encourage imitative R\&D in China, thereby building up its overall R\&D capacity, it also discourages domestic innovation. The Chinese market is quite sizable. The tastes of consumers and technological constraints of producers likely differ greatly from their counterparts in other innovative nations. By strengthening IPR protection, China may induce greater domestic and global innovation that favors local needs (see Diwan and Rodrik 1991, and Evenson and Westphal 1997).

Why does Chinese law inadequately protect the works of its own inventors and artists? Two different cases must be distinguished. In one set of cases, enforcement of copyrights and patents poses a simple tradeoff: domestic inventive activity is encouraged but at the expense of higher consumer prices and larger transfers of copyright and patent royalties to foreigners. The decision to enforce IPRs in these cases depends on the size and the growth potential of the local industry. If the net result of better IPR enforcement is just higher prices in China and the transfer of royalties overseas, there will be little incentive to enforce these IPRs. In these cases, Chinese authorities may use “enforcement lapses" as bargaining devices to gain a better deal from IPR owners concerning licensing fees and royalties. Chinese reluctance to enforce copyrights in CDs 
in late 1995 and early 1996 may have been an example of such behavior — or it may just have been retaliation for U.S. policy towards Taiwan during that period. ${ }^{15}$

In a second set of cases, IPR enforcement is likely to be less vigorous, as enforcement generates an additional cost: reduced growth of the stock of knowledge and human capital. Two examples suffice. First, enforcement of IPRs in college textbooks not only increases textbook prices to students and transfers of copyright royalties overseas, but the higher prices also reduce human capital formation by increasing the cost of an education. ${ }^{16}$ Second, enforcement of some patents reduces imitative R\&D in Chinese industry and thereby reduces the stock of knowledge accumulated via R\&D activity. If the switch to innovative activity in a particular industry depends on the accumulated stock of knowledge, then enforcement of foreign patents in China could delay the onset of innovative activity in that industry. On the other hand, if better patent enforcement induces more foreign firms to locate plants and R\&D activities in China, then there may be increased spillovers of knowledge to Chinese workers, engineers, and scientists.

\section{Direct foreign investment and technology transfer effect}

The effect of IPR protection on FDI is particularly important in our context, as China received US\$40.7 billion in FDI during 2000. Proponents of strengthening IPRs in developing countries frequently cite the benefits it will bring in terms of creating a better environment for technology transfers and inflows of FDI. By enhancing the technological base, technology transfers and FDI contribute to employment and

\footnotetext{
${ }^{15}$ If such "enforcement lapses" are expected as regular moves in a game to reduce rent transfers, then their usefulness as punishment is impaired.

${ }^{16}$ Less IPR enforcement for foreign educational materials has some drawbacks. Foreign works are less likely to be translated into Chinese, as widespread copying reduces compensation to Chinese translators as well as foreign authors.
} 
economic growth. The argument implies that foreign firms would be more likely to share technological information with Chinese affiliates and licensees when local competitors are legally restrained from infringing on the domestic firm's intellectual property (Sherwood, 1991).

When a firm seeks to protect its reputation for quality, however, it may prefer FDI over either exports or transferring technology to a local vendor when intellectual property protection is low (Horstmann and Markusen 1987). Indeed, in interviews with foreign enterprise managers in China, Maskus and Dougherty (1998) recognize a reluctance to license technologies or otherwise transfer technologies to local operations because of perceived weak IPRs. They identify several defensive measures such as the transfer of only old technologies to joint venture partners, the establishment of strict vertical supply chains to monitor quality and to conceal underlying technologies, and sale to only large established firms with a premium placed on quality, i.e., public enterprises or hospitals. Weak IPR protection could also induce firms to decide not to export goods to China or to produce them in China. For example, during the 1990s international seed producers restricted the export of some seed varieties to Chinese farmers due to poorly specified IPRs for new plant varieties in China. ${ }^{17}$

Maskus and Konan (1994) tested the relationship between FDI and IPRs using a cross-sectional sample of 44 countries and found only weak evidence of a positive relationship. ${ }^{18}$ Lee and Mansfield (1996) conducted a similar study based on survey data from nearly 100 US firms regarding their perceptions of a country's IPR protection and

\footnotetext{
${ }^{17}$ China recently upgraded its IPRs protecting plant varieties as part of the package of measures passed to facilitate compliance with TRIPS Agreement.

${ }^{18}$ A wide range of other conditions will play a prominent role in a firm's decision to engage in technology transfer, FDI, or exports. The IPR regime may be a rather minor element in a firm's decision to transfer technology or invest in China.
} 
their investment decisions. Their tests are consistent with the proposition that stronger IPR protection is correlated with a greater volume of FDI. In particular, if 10 percent fewer firms reported a nation as inadequate in IPR protection (versus adequate), Lee and Mansfield would predict an additional inflow of $\$ 140$ million in US FDI per year. ${ }^{19}$ Given the huge recent FDI flows to China, the impact of stronger IPRs is likely to be somewhat higher in China. ${ }^{20}$

\section{THE POLITICAL ECONOMY OF IPRS IN CHINA}

Chinese policymakers face pressure to strengthen the IPR regime from multiple fronts. Insufficient protection of IPRs has been a perennial source of contention in SinoUS relations as well as a stumbling block in China's bid for WTO membership. Yet, perhaps the most effective pressure originates from within. In this section, we provide an overview of the forces for change and those for stagnation within China.

\section{A. Domestic Forces at Work}

Chinese inventors and artists are producing important inventions in some industries, as well as literary, artistic, and musical works. There has been a rapid growth in Chinese patent applications (Table 1). As privatization progresses, many present and former state-

owned enterprises are also seeking means to protect developed or acquired technological innovations (Oksenberg, et al 1996). Consider, for example, dicyclol, a pharmaceutical inhibiting replication of hepatitis $\mathrm{B}$ and $\mathrm{C}$ viruses and reducing hepatitis manifestations.

\footnotetext{
${ }^{19}$ Firms in the Lee and Mansfield study were not questioned regarding their opinions of the Chinese IPR system or their activities in China.

${ }^{20}$ Lee and Mansfield's regression study adjusted for market size but did not include an interaction variable between market size and IPR protection.
} 
Developed by the Pharmaceutical Institute of the Chinese Academy of Medical Sciences, it has been patented in 13 countries and could be a significant source of income for the Academy — if its patent is enforced. Piracy in pharmaceuticals is widespread in China.

In terms of trademarks and copyrights, Maskus and Dougherty (1998) report that the losses in the Chinese entertainment, publishing, and consumer goods industries likely outweigh those of prominent Western firms like Disney and Microsoft. A few examples may be helpful. Mr. Ling Yan, chairman of the Chinese software company, Sun Tendy, estimates that less than 10 percent of the copies of his Chinese language software program, Chinese Star, are legal. Mr. Wang Shuo, the author of numerous best-selling novels, has encountered thousands of infringing copies of his books in bookstalls in China's major cities. One of China's leading rock-and-roll artists, Mr. Cui Jian, had sold 1.2 million CDs and audio tapes through 1996, but he estimated that over 10 million infringing copies are in circulation. ${ }^{21}$ Hongtashan cigarettes and Maotai liquor have been prominent targets of counterfeiting. ${ }^{22}$

Different levels of development in China's coastal provinces and its interior provinces may slow down the transition to stronger IPRs (Maskus and Dougherty 1998). Poorer interior provincesl have less interest in strengthening IPRs than richer, more technologically-advanced coastal provinces, as the rent-transfer effects are likely to dominate innovation and technology-transfer effects in the short run in poor provinces, as firms in poor provinces using imitated technologies will have to license the technology and consumers in poor provinces will have to pay higher prices for the firms' products. ${ }^{23}$

\footnotetext{
${ }^{21}$ See Matt Forney, "Now We Get It," Far Eastern Economic Review, 15 February 1996, pp. 40-43.

${ }^{22}$ Maskus and Dougherty (1998).

${ }^{23}$ Higher licensing fees could have a variety of effects. They could reduce profits of a fixed number of firms facing inelastic demands; they could put some firms out of business (as higher fixed costs can reduce the optimal number of firms in the market); they could put some firms out of business due to consumer
} 
Even inside richer provinces, the industries capable of producing new technologies may often be small and poorly organized, precisely because of the country's lack of IPR protection. Both factors contribute to slowing down the transition to stronger IPRs.

Given this scenario, foreign pressure to strengthen domestic IPR laws may provide an effective mechanism for overcoming the deadweight losses generated by the interest group logjam (La Croix 1992). The developed country's threat to retaliate against the developing country's exporters will induce the exporters to increase their lobbying activities to strengthen IPRs. In some cases the enhanced coalition pushing for stronger IPRs will be sufficient to override strong, organized domestic lobbies that would suffer losses under a stronger IPR regime. From the perspective of a welfare-maximizing social planner, foreign pressure has, however, a major drawback, as developed countries may push for a transition path to stronger IPRs that is faster than the optimal path for the developing country. We are, therefore, left with the paradox that foreign pressure with respect to IPRs may be privately welcomed by the domestic government yet publicly resisted in order to limit its overreach by foreign countries.

It is also immensely difficult for China to enforce IPRs effectively without a broader, well-established legal infrastructure. Even in the United States, intellectual property is amongst the most sophisticated and rapidly changing areas of law (Oksenburg et al., 1996). With private ownership a somewhat recent phenomenon, laws governing private property of any sort are neither deep nor broad. Ross (1996) observed that the Chinese central government "simply lacks the authority" to end much of the piracy in the Chinese economy. IPR regulations mandated by the central government are often ignored by corrupt local officials who share in the profits from piracy. China has

response to the higher prices; or there could a combination of the last two effects. 
established a special court system that is dedicated to resolving IPR disputes. Jenckes (1997) argued that "these new courts do not provide a forum for American businesses seeking to uphold their copyrights." They often lack appropriate mechanisms for enforcing their decisions. Access to the IPR courts by individuals and small firms is also limited by the requirement that a proportion of the claimed damages be posted as a bond.

With public enforcement efforts limited by China's antiquated court system, Chinese and foreign firms are organizing into associations which would undertake additional private enforcement, place pressure on government to continue enforcement efforts, and keep the issue before the public. Shanghai's first anti-piracy association was formed in November 2000 by 43 firms with well-known trademarks. ${ }^{24}$ The State Bureau of Copyrights has established a national "anti-piracy union." The union has administrative power to investigate, gather evidence, report activities, and even issue penalties.

Progress on IPR enforcement may, therefore, ultimately proceed at the same slow pace as legal reform in China. Strengthening IPR enforcement is particularly costly in a developing country, as it requires not only the application of scarce legal professionals but also the application of scarce scientific and engineering professionals to this activity.

A key source of pressure on China's government to strengthen IPRs comes from associations in China representing foreign businesses and joint ventures. ${ }^{25}$ Maskus and Dougherty (1998) survey managers in Chinese high-technology industries, such as information technology and software, chemicals and pharmaceuticals, and biotechnology. Discussed above, they find that foreign enterprise and joint venture managers in China are much more likely to perceive IPR enforcement as a stumbling block than their local

\footnotetext{
${ }^{24}$ Foreign and Chinese software companies have formed a similar organization.

${ }^{25}$ We thank a referee for pointing this out.
} 
enterprise counterparts. Direct foreign investment has been a source of economic growth and technology transfer. Thus pressure placed on China's government from foreign business associations is encouraging change.

\section{B. The Political Economy of U.S. Pressure}

American pressure on China followed a decade of pressure on other Asian developing countries to reform their IPRs. From the early 1980s the United States has threatened countries with weak IPR laws and institutions through its "Special 301" provisions of U.S. trade law (Konan, et al 1995). Special 301 allows the U.S. Trade Representative to investigate foreign protection of U.S. intellectual property, to negotiate for higher standards of protection, and to retaliate with trade sanctions if negotiations fail.

\section{(Table 2)}

As Asian IPR laws approached the standards set in developed countries, the focus of U.S. and European pressure shifted to monitoring enforcement of IPRs, particularly computer software and entertainment copyrights. Table 2 displays estimates compiled by the International Intellectual Property Alliance of piracy rates and lost sales by U.S. firms in Asia during $1995 .^{26}$ Despite increased enforcement efforts by most Asian countries, it is notable that piracy rates on a broad array of copyrighted products were high not only in China but throughout the region. ${ }^{27}$

The unilateral pressures from the United States during the 1980s may have been due to the relatively weak set of international treaties coordinating and harmonizing national IPR regimes. The WTO Agreement on Trade-Related Aspects of Intellectual

\footnotetext{
${ }^{26}$ The piracy estimates clearly have severe measurement problems. The survey respondents obviously have incentives to report high rates of piracy to stimulate U.S. government pressure on foreign governments. The rates for business software are likely to be overstated because they do not properly account for customized application software.

${ }^{27}$ IIPA data for $1999-2000$ indicates piracy rates in China have fallen from $100 \%$ to $90 \%$ for motion pictures, have remained constant at $99 \%$ for entertainment software, and have increased from $54 \%$ to $85 \%$ for music CDs. See http://www.iipa.com/pdf/2001_Apr30_USTRLOSSESrev.pdf.
} 
Property Rights (TRIPS) represents a dramatic breakthrough in the international regime, as it specifies strong minimum standards for the protection and enforcement of copyrights, patents, trade secrets, trade and service marks, and indicators of geographic appellation. The result is extensive, but not complete, harmonization of national IPR regimes among countries that are parties to the WTO Agreement. ${ }^{28}$

\section{$\underline{\text { Future Market for U.S. Firms Selling IPR-Intensive Goods }}$}

Chinese economic growth averaged about 7.5 percent between 1978 and 1998, yet average Chinese per capita incomes remain quite low by international standards. ${ }^{29}$ Per capita income in 1998 was just US\$830, using exchange rate conversion, or US\$3,105, using purchasing power parity conversion. Since incomes using exchange rate conversions are most relevant for purchasing IPR-intensive imports, it is worth asking whether there is sufficient Chinese demand for U.S. firms to enforce against infringing uses of their technologies, trademarked products, or copyrighted products. Income disparities within China may be the source of significant demand. For example, in 1999, the top quintile of urban households had average per capita incomes that were 88 percent higher than urban households in the middle-income quintile (China Statistical Yearbook, 2000, pp. 315). Urban residents had average annual per capita incomes that were 165 percent higher than rural residents. Given that there were roughly $60-70$ million people in the top quintile of urban households in 1999, this market segment could have provided sufficient demand for IPR-intensive goods to warrant U.S. pressure for stronger IPRs in the 1990s. Current demand must also be coupled with expected large increases in future demands. If China's GDP growth rates continue at the 6.2 percent pace exhibited between 1986 and 1998, then

\footnotetext{
${ }^{28}$ See Primo-Braga (1996) for discussions of the TRIPS agreement.

${ }^{29}$ Recent revisions of Chinese national accounts by two economists reduced China's GDP growth rate from 9.2 percent to 6.2 percent between 1986 and 1998 (Maddison 1999) or, alternatively from 10 percent to 7.5 percent between 1978 and 1998 (Young 2000).
} 
average Chinese incomes will double in less than 12 years. Efforts by the United States to strengthen IPR laws and institutions in China may, therefore, be best interpreted as current investments in China's current and growing future demands for IPR-intensive goods.

\section{Changing Comparative Advantage}

U.S. government initiatives to protect IPRs in China and the rest of Asia could be driven by changes in U.S. comparative advantage as well as by U.S. trade deficits. We examine changes in the overall trade of IPR-intensive goods by China and the United States and the trade in IPR-intensive goods between the two countries to determine whether there is any evidence for this contention. (Table 3)

Table 3 presents import and export data (millions of dollars) for copyrightprotected, patent-protected, and trademark-protected goods. We adopt the classifications used by Keith Maskus (1990, 1993), who selected goods prominent in international disputes over IPRs. Our analysis compares trade figures in 1987, the first year in which China reports 3-digit SITC trade figures, with trade data from 1994, a year in which IPR disputes between the United States and China were simmering, and from the latest year available, 2000. U.S. exports of patent goods to China grew rapidly between 1987 and 2000, but in most sectors the China trade did not grow as fast as overall U.S. exports of patent goods. By contrast, U.S. imports of trademarked goods from China also grew rapidly between 1987 and 2000, but in most sectors the China trade grew faster than overall U.S. imports of trademarked goods. U.S. exports of copyrighted goods also grew between 1987 and 2000 but remain very small and comprise less than 10 percent of Chinese imports of copyrighted goods in 2000. (Table 4) 
Table 4 reports simple indexes of revealed comparative advantage in manufacturing (RCAM) of IPR-intensive goods. RCAMs are computed as the ratio of sector exports to sector imports divided by the ratio of total manufacturing exports to total manufacturing imports. An RCAM above unity indicates an industry with an above average export strength relative to overall manufacturing trade, while an RCAM below unity indicates a relatively strong import position for that sector. The United States has a consistently strong comparative advantage in the patented sectors of medical and pharmaceutical products (SITC 541), surveying, measuring, drawing, and gas control instruments (SITC 874), other machinery for special industries (SITC 728), electromedical and x-ray equipment (SITC 774), and alcohols (SITC 512). This pattern of comparative advantage persists when we calculate sector RCAMs for U.S. trade with China. ${ }^{30}$ Despite high U.S. RCAMs for many patent goods, Chinese imports of these goods generally remain low, and the U.S. share of this limited trade also remains low. For example, the U.S. share is 13 percent in electro-medical and x-ray equipment, 7 percent in alcohols, and 21 percent in surveying, measuring, drawing, and gas control instruments. Naturally, the United States actively seeks to prevent local infringement of IPRs in these sectors in China. Indeed, the low U.S. trade volume in these sectors may be attributable to weak Chinese IPRs if U.S. firms are concerned about the deterioration of their patents or if infringing Chinese production is substituting for U.S. exports.

In contrast, U.S. imports in trademark-sensitive sectors are heavily focused on China, and the share of Chinese firms in U.S. imports increased in most trademarksensitive sectors between 1987 and 2000. For example, starting with an 18.5 percent share of U.S. imports in toys and indoor games (SITC 8942) in 1987, China captured

\footnotetext{
${ }^{30}$ The pharmaceutical sector is a notable exception to this pattern.
} 
nearly 83 percent of the U.S. import market by 2000; and China's import share of the U.S. travel goods and handbags sector (SITC 831) grew from 16 percent in 1987 to 50 percent in 2000. There was similar rapid growth in China's import share in the clothing (SITC 84), watches (SITC 885), and furniture sectors (SITC 821). While China has a clear comparative advantage in these sectors, with astronomical RCAMs in clothing (SITC 84) and travel goods and handbags (SITC 831), the intellectual property component of these products (trademarks) tends to be foreign-owned. Indeed, China's strong comparative advantage in these sectors may be partially attributable to relatively weak protection for foreign, especially U.S., trademarks. The U.S. pressure on China to strengthen their IPRs reflects, in part, the desire to protect its intellectual property in these heavily traded trademark-sensitive sectors.

The volume of trade in copyrighted goods seems very small, particularly given the U.S. comparative advantage in many copyrighted goods, such as literary works, computer software, music and films. The low trade flows for copyright-intensive goods in Tables 3 and 4 may, in fact, distort the measured RCAMs as well as provide additional evidence that extensive piracy of these goods is occurring in China.

Related is the American concern over its ballooning overall trade deficit, and the increasingly large bilateral trade deficit with China (Table 5). The merchandise deficit with China reached US\$20 billion in 1994 and US\$84 billion in 2000, about 20 percent of the total U.S. trade deficit. ${ }^{31}$ (Table 5)

\footnotetext{
${ }^{31}$ Garbaccio (1995, pp. 6-8) notes that official U.S. figures overstate the U.S.-China bilateral trade deficit by about one-third. Moreover, although U.S.-China trade deficits have increased by 900 percent between 1987 and 1994, the combined deficit with Taiwan, Hong Kong, and China increased by only 40 percent.
} 
The conventional wisdom among trade economists is that bilateral trade deficits are not a concern, as they reflect patterns of comparative advantage and are generally offset by surpluses with other trading partners. Large U.S. deficits with energy producers, e.g. Saudi Arabia, are typically taken for granted. In practice, trade deficits with particular countries have been the subject of special attention from the U.S. President and Congress. Throughout the 1980s and 1990s, for example, the U.S. government pressured the Japanese government to adopt a wide variety of importpromotion policies aimed at balancing trade.

Cox and Ruffin (1998), have recently shown that bilateral trade deficits may matter in a multi-country trade war. In a three country, non-retaliatory environment bashing a deficit country with a small tariff is beneficial for a large country. The bilateral tariff improves the terms of trade of most favored imports (originating from the deficit country) at the expense of least favored imports (from the surplus country). Of course with the tariff the volume of trade falls for favored imports. Hence, an optimal bilateral tariff can be computed. As in Johnson's (1953) classic tariff retaliation model, the Nash equilibrium is comparable to a prisoner's dilemma where all countries lose from a 'country-bashing' trade war. Given that U.S. imports from China are IPR intensive, threats against IPR infringements could be viewed as an attempt to reduce trade deficits with China, and thus improve American terms of trade. IPRs may be the preferred U.S. policy instrument, as they are less vulnerable to retaliation than tariffs.

\section{$\underline{\text { Infringing Exports }}$}

U.S. firms have typically been particularly concerned with infringing uses of their technologies, trademarked products, or copyrighted products when the infringing products are exported to neighboring economies. Exports by Chinese firms of infringing CDs to 
Hong Kong in late 1995 were a major trigger for the USTR's investigation of China, as U.S. firms complained that Chinese IPR violations reduced sales by U.S. firms in Hong Kong's lucrative market as well as in mainland China. Why, however, are infringing export activities of particular concern? Isn't a lost sale in Hong Kong equivalent to a lost sale in China?

There are at least four reasons for U.S. firms and the U.S. government to focus on infringing exports. First, pirate operations with economies of scale in production become more viable with infringing exports, as pirates gain additional markets for their products. Limiting IPR pirates to the Chinese markets will hamper movement down their average cost curves. Second, in foreign markets with inelastic demands, even small amounts of additional supply can lead to significant reductions in the price, producing a large loss for U.S. firms on legitimate sales. Third, infringing exports place additional burdens on enforcement in the receiving country, effectively transmitting China's enforcement problems to a second country. The additional burden on police and courts could reduce the overall effectiveness of the importing country's enforcement efforts. Finally, increasing integration of national markets has forced many countries to standardize their IPR policies across markets, as markets become more difficult to isolate. In this environment, the U.S. is less likely to tolerate infringing exports of its firms' products, as this may provide a signal to other countries that such behavior is tolerated. ${ }^{32}$

China's behavior with respect to infringing exports was particularly important to the United States in the mid-1990s. Much of China's growth after 1990 was export driven, and U.S. firms did not want to face additional competition in second countries from pirated versions of their own products. Moreover, the U.S. government had pressured many of

\footnotetext{
${ }^{32}$ The U.S. may also maintain a tough stance on flagrant TRIPS violations to set a global example.
} 
China's Asian trading partners to improve their IPR standards and enforcement during the 1980s and 1990s. These countries would be not pleased with dual U.S. standards on domestic piracy and infringing imports.

\section{$\underline{\text { U.S. Presidential Elections and the Electoral College }}$}

The increasing electoral importance of California in U.S. presidential and congressional elections has led U.S. politicians to focus more attention on California's economy and interest groups. California has 54 "winner-take-all" electoral votes in U.S. presidential elections, or 20 percent of the 270 electoral votes required to win the presidency. ${ }^{33}$ Several studies have confirmed that federal policies are designed to maximize electoral votes, among other things. For example, Wright (1974) and Wallis (1987) found that spending on New Deal programs was determined by a state's electoral votes as well as its economic conditions. ${ }^{34}$ Other studies indicate that presidential decisions are biased towards building winning coalitions in large, electorally important states. For example, Grier, McDonald, and Tollison (1995) found that presidential veto decisions were influenced by the floor votes of senators from closely contested large states. In general, presidential candidates have incentives to identify important swing interest groups in closely contested, larger states and reward them with income transfers.

We examine these propositions by examining whether the U.S. government has pushed for stronger IPRs because U.S. IPR-intensive industries are more heavily concentrated in states with more electoral votes. Following our earlier analysis of U.S.China trade patterns, we adopt the Maskus $(1990,1993)$ categorization of IPR-intensive

\footnotetext{
${ }^{33}$ Electoral votes are the sum of the number of representatives in each state and the number of senators (2). States with low populations have a high number of electoral votes per voter, while states with high populations have a lower number of electoral votes per voter.

${ }^{34}$ See also Wallis (1999), Wallis (2001), and Fleck (2001) for a discussion of evidence on small-state bias in legislation enacted by the federal government.
} 
industries and use it with the 1997 Economic Census of the United States to determine the number of employees and the share of employment in each state concentrated in copyright-intensive, trademark-intensive, and patent-intensive industries. ${ }^{35}$ Since some employment data were presented as ranges of values, we calculate three different measures of each employment variable, using the maximum value, the minimum value, and the averages of the bounds of the employment range. The correlations between the levels and shares of IPR-intensive employment with electoral votes, using both aggregate and specific measures of IPR intensity, are reported in Table 6. There is a positive and statistically significant relationship between the number of a state's electoral votes and all four measures of IPR-intensive employment levels. This is, of course, to be expected, as large states often have more employees in most industries due to their large populations. To adjust for this scale effect, we estimate the correlation between employment shares in IPR-intensive industries and electoral votes and find that the correlation is positive but statistically insignificant. We note, however, that California is an outlier, with the largest number of electoral votes and a high percentage of employment in IPR-intensive industries. (Table 6)

Industry influence on government policy is partly determined by its scale and distribution across states but is also a function of the industry's organization for political action. U.S. IPR-intensive industries became increasingly active players in the U.S. political arena as they became more export-oriented in the 1970s and 1980s. In the 1980s, numerous new industry trade associations were formed in the entertainment and computer industries, many with the narrow purpose of lobbying the federal government

\footnotetext{
${ }^{35}$ The Census data used in our analysis are available at http://www.census.gov/epcd/www/econ97.html.
} 
to obtain better enforcement of foreign copyrights on entertainment products and computer software. $^{36}$

\section{ENDGAME: CHINA AND THE WORLD TRADE ORGANIZATION}

Since the 1996 dispute over copyright enforcement, IPR disputes between China and the United States have cooled down. Some of the change can be attributed to the additional pressure for stronger IPRs generated by high per capita income growth in China and accompanying creative activity by firms and individuals. Part of the change can also be attributed to the conclusion of the 1994 GATT agreement and the resultant formation of the World Trade Organization in 1995. The new GATT agreement held particular promise for China for a number of reasons. First, it offered an opportunity to disable trade sanctions and annual renewals of most-favored-nation status as levers of U.S. policy. Second, its gradual dismantling of the country quotas on textiles (as specified in the Multifibre Trade Agreement) would be particularly beneficial to China's rapidly growing textile industry. Third, it offered the prospect of secure markets for the growing flood of labor-intensive exports coming from a wide variety of China's industrial sectors. ${ }^{37}$ Finally, it provided the appropriate political leverage for the Chinese government to continue its program to reform and privatize most state enterprises. The stumbling block was that only WTO members could reap these potential gains and China was not a member.

To become a member, China had to negotiate bilateral agreements with 37 WTO members requesting negotiations. An agreement with the United States to establish

\footnotetext{
${ }^{36}$ Pamuela Samuelson noted (in a May 1998 personal conversation) that the Hollywood-based entertainment industry has lobbied hard for tough immediate enforcement of IPR laws in Asia, while the Silicon Valley-based computer industry has been more content with gradualist measures. Trade associations in both industries became more active in the 1980s because exports of their IPR-protected just as technological changes markedly reduced the cost of pirating copyrighted products.

${ }^{37}$ See Abe and Lee (2001).
} 
permanent normal trade relations was concluded, after many fits and starts, in November 1999 and signed into law by President Clinton in October 2000. An agreement with the European Union quickly followed. Both agreements called for China to adhere to TRIPS immediately upon accession to WTO membership. The WTO approved a multilateral Protocol of Accession for China on September 17, 2001 and approved its membership on November 10, 2001 at the Doha WTO Summit. China formally became a member of the WTO on December 11, 2001.

The siren call of the potential benefits from WTO membership fundamentally changed China's approach to IPRs. WTO membership requires that each member adhere to the strong minimum standards for intellectual property set forth in the 1994 TRIPS Agreement. $^{38}$ It became quickly apparent that for China to join the WTO, its IPR laws and enforcement practices would have to be strengthened substantially. While strengthening IPR institutions still implied substantial costs for some sectors of the Chinese economy, the tie-in with WTO membership had the effect of significantly ratcheting up the benefits from strengthened IPRs after 1995. ${ }^{39}$ The reduced conflict over IPRs after 1995 has not occurred because piracy has been curtailed in China-it remains a significant problem. Instead it reflects the recognition by the U.S. government that the Chinese government had changed the priority assigned to strengthening its IPR institutions to meet TRIPS standards.

\footnotetext{
${ }^{38}$ See discussion of TRIPS in Section IV above. The WTO requires its members to adopt the TRIPS Agreement without reservations. After 2005, even the least developed members must fully adopt TRIPS. ${ }^{39}$ This argument raises the question of the rationale behind the 1995/1996 copyright disputes between China and the United States. One possible explanation is that the conflict was retaliation for U.S. policies on Taiwan opposed by China. A second explanation is that many of the benefits of WTO membership, i.e., the phase-out of the Multi-Fibre Arrangement, were still years away. By delaying its accession, China would maximize the present value of net benefits from membership. A third explanation is that it took time for the Chinese government time to develop and implement new policies with respect to IPRs after the WTO was established in 1995.
} 
The TRIPS Agreement also induced changes in U.S. IPR policy. Prior to TRIPS, there were virtually no international standards governing the strength of IPRs. ${ }^{40}$ Annual "Special 301" reviews of foreign IPRs and threats of sanctions to offending states were the main policy tool used by the U.S. government to protect intellectual property of U.S. citizens and corporations in foreign countries. Since the passage of TRIPS, the United States has continued to utilize Special 301 reviews but has shifted the focus of enforcement efforts towards WTO dispute resolution panels. As of September 2001, the United States had brought nine IPR cases to WTO panels and prevailed (or settled without litigation) in all cases. ${ }^{41}$

\section{A BROADER VIEW OF IPRS IN CHINA}

Despite the rhetorical heat generated by the IPR issue, both countries have acted responsibly with respect to actions taken to resolve IPR differences. Differences have been discussed, and productive agreements have repeatedly been reached. The extent of sanctions threatened by both China and the United States has been limited, and in general the disputes produced only minor disruptions of U.S.-China trade and investment flows during the 1990s. The rhetoric has often been heated because politicians and leaders on both sides do not want to appear to be giving in to the other country's demands, particularly during election years and leadership transitions. While these political factors have lengthened negotiations, it is important to recognize that they have not prevented the two sides from reaching agreements; the Chinese government from making substantive changes in IPR law and enforcement; and the U.S. government recognizing the limits of Chinese enforcement efforts.

\footnotetext{
${ }^{40}$ There were international standards pertaining to other aspects of IPRs, e.g. national treatment.

${ }^{41}$ One IPR case filed by the United States is still in consultations at WTO, and another is being monitored.
} 
The U.S.-China disputes over IPRs must not be viewed in isolation from overall relations. Friction over other issues may have induced China to slow progress on IPR issues to gain leverage in the other disputes. While the 1996 IPR dispute may well have been an attempt to "jawbone" entertainment companies to provide better licensing terms for their products, it may also have been a studied response to the U.S. decision to allow Taiwan's president to visit the United States.

More broadly, our analysis leads us to conclude that many developing countries, including China, would prefer to set different IPR standards for different industries at different stages of development. ${ }^{42}$ Such differentiation is, however, inconsistent with the laws and institutions of developed countries and with the new world IPR standards set forth in the TRIPS Agreement. With increasing globalization and integration of world markets, the United States and other developed countries have been reluctant to apply differential IPR standards to developing countries due to the potential for infringing exports and for substantial lost sales to their emerging middle classes. The "one-size-fitsall” standard will, however, sometimes produce too much IPR protection too early in some developing countries and is likely to be a source of continued international conflict between developed and developing countries.

${ }^{42}$ Konan, La Croix, Roumasset and Heinrich (1995) discuss this issue in more detail. 


\section{REFERENCES}

Abe, S., and C. Lee (2001), "Economic Development in China and its Implications for Japan," in M. Blomstrom, B. Gangnes, and S. La Croix, eds., Japan's New Economy: Continuity and Change in the Twenty-First Century, New York: Oxford University Press.

Alford, W.P. (1995), To Steal a Book is an Elegant Offense: Intellectual Property Law in Chinese Civilization, Stanford: Stanford University Press.

Besen, S.M. and L.J. Raskind (1991), "An Introduction to Law and Economics of Intellectual Property," Journal of Economic Perspectives (5) 3-28.

Blakeney, M. (1996), "The Impact of the TRIPS in the Asia Pacific Region," European Intellectual Property Review 18, 544-554.

Chengsi, Z. (1997), “TRIPS and Intellectual Property Protection in China,” European Intellectual Property Review 19, 243-246.

Chin, J., and G. Grossman (1990), "Intellectual Property Rights and North-South Trade," in R. Jones and A.O. Krueger, eds. The Political Economy of International Trade: Essays in Honor of Robert E. Baldwin. Cambridge, Mass.: Blackwell.

Cox, W.M., and R.J. Ruffin (1998), “Country-Bashing Tariffs: Do Bilateral Trade Deficits Matter?” Journal of International Economics 46, 61-72.

Deardorff, A.V. (1990), "Welfare Effects of Global Patent Protection," Economica 59, 33-51.

Declet, R.A., Jr. (1997), "Protecting American Intellectual Property in China: The Persistent Problem of Software Piracy," New York International Law Review 10, 57-76.

Diwan, I. and D. Rodrik (1991), "Patents, Appropriate Technology, and North-South Trade," Journal of International Economics 30, 27-47.

Elkan, R. van, (1996), "Catching Up and Slowing Down: Learning and Growth Patterns in an Open Economy," Journal of International Economics 41, 95-112.

Evenson, R.E. and L.E. Westphal (1997), “Technological Change and Technology Strategy," in J. Behrman and T.N. Srinivasan, eds., Handbook of Development Economics, Vol. IIIA. Amsterdam: Elsevier.

Fleck, Robert K. (2001), "Population, Land, Economic Conditions, and the Allocation of New Deal Spending,” Explorations in Economic History 38, 296-304.

Fung, K.C., and Lawrence J. Lau (1996), The China-United States Bilateral Trade Balance: How Big is It Really? Stanford: Asia/Pacific Research Center. 
Garbaccio, R.F. (1995), “U.S.-China Trade Relations: 1972-95,” unpublished manuscript, Kennedy School of Government, Harvard University.

Gould, D.M., and W.C. Gruben (1996), "The Role of Intellectual Property Rights in Economic Growth," Journal of Development Economics 48, 323-350.

Grier, K.B., M. McDonald, and R.D. Tollison, "Electoral Politics and the Executive Veto: A Predictive Theory," Economic Inquiry 33, 427-440.

Grossman, G.M. and E. Helpman (1991). Innovation and Growth in the Global Economy. Cambridge: MIT Press.

Grossman, G.M. and E. Helpman (1995), “Technology and Trade,” in G. M. Grossman and K. Rogoff, eds., Handbook of International Economics, Vol. III. Amsterdam: North-Holland, pp.1279-1337.

Gruen, N., I. Bruce, and G. Prior (1996), Extending Patent Life: Is it in Australia's Economic Interest? Staff Information Paper, Australia Industry Commission, Canberra, Australia.

Helpman, E. (1993), "Innovation, Imitation, and Intellectual Property Rights," Econometrica 61, 1247-1280.

Horstmann, I.J. and J.R. Markusen (1987), "Licensing v. Direct Investment: A Model of Internalization by the Multinational Enterprise," Canadian Journal of Economics 20, 464-81.

Jenckes, K.S. (1997), "Protection of Foreign Copyrights in China: The Intellectual Property Courts and Alternative Avenues of Protection," Southern California Interdisciplinary Law Journal 5, 551-571.

Johnson, H.G. (1954), “Optimum Tariffs and Retaliation,” Review of Economic Studies 21, 142-153.

Kawaura, A., and S.J. La Croix (1995), "Japan's Shift from Process to Product Patents in the Pharmaceutical Industry: An Event Study of the Impact on Japanese Firms," Economic Inquiry 33, 88-103.

Konan, D.E., S.J. La Croix, J.A. Roumasset, and J. Heinrich (1995), "Intellectual Property Rights in the Asia-Pacific Region: Problems, Patterns, and Policies," Asian-Pacific Economic Literature 9, 13-35.

Kolton, G.S. (1996), “Copyright Law and the People's Courts in the People's Republic of China: A Review and Critique of China's Intellectual Property Courts," University of Pennsylvania Journal of International Economics and Law 17, 415460. 
La Croix, S.J. (1998), "Intellectual Property and APEC,” in V.K. Aggarwal and C. Morrison, eds., Asia-Pacific Crossroads: Regime Creation and the Future of $A P E C$. New York: St. Martin's Press.

La Croix, S.J. (1994), Intellectual Property Rights in ASEAN and the United States: Harmonization and Controversy, Honolulu: East-West Center.

La Croix, S.J. (1992), “The Political Economy of Intellectual Property Rights in Developing Countries," In J. Roumasset and S. Barr, eds., The Economics of Cooperation: East Asian Development and the Case for Pro-Market Intervention. Boulder, Colorado: Westview Press.

La Croix, S.J., and A. Kawaura (1996), "Product Patent Reform and its Impact on Korea's Pharmaceutical Industry," International Economic Review, 10, 109-124.

Lee, J-Y, and E. Mansfield (1996), "Intellectual Property Protection and U.S. Foreign Direct Investment," Review of Economics and Statistics 78, 181-186.

Maddison, A. (1999), Chinese Economic Performance in the Long Run. Washington, D.C.: Brookings Press.

Maskus, K.E. (1990), "Normative Concerns in the International Protection of Intellectual Property Rights," World Economy 13, 387-409.

Maskus, K.E. (1993), “Trade-Related Intellectual Property Rights,” The European Economy 52, 157-184.

Maskus, K.E. (2000), Intellectual Property Rights in the Global Economy. Washington, DC: Institute for International Economics.

Maskus, K.E. and S.M. Dougherty (1998), "Intellectual Property Rights and Economic Development in China," The National Bureau of Asian Research Working Paper.

Maskus, K.E., and D. Konan (1994), “Trade-Related Intellectual Property Rights: Issues and Exploratory Results," In A.V. Deardorff and R.M. Stern, Analytical and Negotiating Issues in the Global Trading System. Ann Arbor: University of Michigan Press.

Maskus, K.E., and M. Penubarti (1995), "How Trade-Related are Intellectual Property Rights?" Journal of International Economics 39, 227-248.

National Bureau of Statistics, PRC (various years), China Statistical Yearbook. Beijing: China Statistics Press.

Oksenberg, M., P.B. Potter, and W.B. Abnett (1996), Advancing Intellectual Property Rights: Information Technologies and the Course of Economic Development in China. Seattle: National Bureau of Asian Research. 
Park, W.G. (1998), "Patent Systems in APEC: Role in Nontariff Trade Barriers and Strategic Trade Policy," in Economic Implications of Liberalizing APEC Tariff and Nontariff Barriers to Trade, Publication 3101. Washington, DC: U.S. International Trade Commission, pp. 6.1 - 6.25.

Park, W.G., and C. Ginarte (1997), "Intellectual Property Rights and Economic Growth," Contemporary Economic Issues 15, 51-61.

Perkins, F.C. (1997). "Export Performance and Enterprise Reform in China's Coastal Provinces," Economic Development and Cultural Change 45, 501-540.

Primo Braga, C.A. (1996), “Trade-Related Intellectual Property Issues: The Uruguay Round Agreement and its Economic Implications," In W. Martin and L.A. Winters, eds. The Uruguay Round and the Developing Countries, New York: Cambridge University Press.

Pun, K.H. (1996), "Protection of Well-known Goods in China," European Intellectual Property Review 18, 537-543.

Rapp, R.T., and R.P. Rozek (1990), "Benefits and Costs of Intellectual Property Protection in Developing Countries," Journal of World Trade 24, 75-102.

Ross, R.S. (1996), “Enter the Dragon,” Foreign Policy 104, 18-26.

Sherwood, R.M. (1990), Intellectual Property and Economic Development, Boulder, CO: Westview Press.

Subramanian, A. (1995), Trade-Related Intellectual Property Rights and Asian Developing Countries: An Analytical View, Presented at the Conference on Emerging Global Trading Environment and Developing Asia, Manila, May 29-30, 1995.

Tabatchnaia-Tamirisa, N., and D.E. Konan (1997), "Consequences of IPR Harmonization for the North-South Technology Gap," Unpublished paper, Department of Economics, University of Hawaii.

Taylor, M.S. (1994), “TRIPs, Trade, and Growth,” International Economic Review 35, 361-81.

United Nations (1987, 1990, 1994), Commodity Trade Statistics. New York, N.Y.: United Nations.

Wallis, J.J. (1987), "Employment, Politics, and Economic Recovery during the Great Depression," Review of Economics and Statistics 69, 516-520.

Wallis, J.J. (1998) "The Political Economy of New Deal Spending Revisited, Again: With and without Nevada," Explorations in Economic History 35, 140-170. 
Wallis, J.J. (2001), “The Political Economy of New Deal Spending, Yet Again: A Reply to Fleck," Explorations in Economic History 38, 305-314.

Wright, G. (1974), “The Political Economy of New Deal Spending: An Econometric Analysis, Review of Economics and Statistics 56, 30-38.

Wu, C. (1995), "Innovation, Patenting, and International Competitiveness: Empirical Evidence from China," Seoul Journal of Economics 8, 231-254.

Yeh, M. (1996), "Up Against a Great Wall: The Fight Against Intellectual Property Piracy in China," Minnesota Journal of Global Trade 5, 503-525.

Young, A. (2000), Gold into Base Metals: Productivity Growth in the People's Republic of China During the Reform Period, NBER Working Paper \# 7856.

Yu, J. (1994), "Protection of Intellectual Property Rights in the P.R.C.: Progress, Problems, and Proposals," UCLA Pacific Basin Law Journal 13, 140-162. 
TABLE 1

\section{CHINA'S PATENT APPLICATION AND GRANTING RATIO}

\begin{tabular}{|c|c|c|c|c|c|c|}
\hline \multirow[b]{2}{*}{ Year } & \multicolumn{3}{|c|}{ Domestic Patents } & \multicolumn{3}{|c|}{ Foreign Patents } \\
\hline & Applications & Granted & $\begin{array}{c}\text { Ratio } \\
(\%)\end{array}$ & Applications & Granted & $\begin{array}{c}\text { Ratio } \\
(\%)\end{array}$ \\
\hline 1985 & 9,411 & 111 & 1.2 & 4,961 & 27 & 0.5 \\
\hline 1986 & 13,680 & 2,671 & 19.5 & 4,829 & 353 & 7.3 \\
\hline 1987 & 21,663 & 6,401 & 29.5 & 4,414 & 410 & 9.3 \\
\hline 1988 & 28,582 & 11,643 & 40.7 & 5,429 & 627 & 12.0 \\
\hline 1989 & 27,367 & 15,480 & 56.6 & 5,538 & 1,649 & 29.8 \\
\hline 1990 & 36,585 & 19,304 & 52.8 & 4,884 & 3,284 & 67.2 \\
\hline 1991 & 45,395 & 21,178 & 46.7 & 4,645 & 3,438 & 74.0 \\
\hline 1992 & 61,788 & 28,311 & 45.8 & 5,347 & 3,164 & 59.2 \\
\hline 1993 & 68,153 & 56,882 & 83.5 & 9,123 & 5,245 & 57.5 \\
\hline 1994 & 67,807 & 39,777 & 58.7 & 9,928 & 3,520 & 35.5 \\
\hline 1995 & 68,880 & 41,248 & 59.9 & 14,165 & 3,816 & 26.9 \\
\hline 1996 & 82,193 & 39,721 & 48.3 & 20,542 & 4,059 & 19.8 \\
\hline 1997 & 90,048 & 46,379 & 51.5 & 24,160 & 4,613 & 19.1 \\
\hline 1998 & 96,233 & 61,378 & 63.8 & 25,756 & 6,511 & 25.3 \\
\hline
\end{tabular}

Source: 1985-1993 from Wu (1995), p. 239; 1993-1998 from China Patent Office. 
TABLE 2

ESTIMATES OF U.S. LOSSES DUE TO ASIAN PIRACY OF U.S. INTELLECTUAL PROPERTY IN 1996

\begin{tabular}{|c|c|c|c|c|c|c|}
\hline Country & $\begin{array}{l}\text { Motion } \\
\text { Pictures } \\
(\mathrm{US \$ m})\end{array}$ & $\begin{array}{l}\text { Piracy } \\
\text { Rate } \\
(\%)\end{array}$ & $\begin{array}{c}\text { Music } \\
\text { CDs } \\
\text { (US\$m) }\end{array}$ & $\begin{array}{l}\text { Piracy } \\
\text { Rate } \\
(\%)\end{array}$ & $\begin{array}{c}\text { Entertainment } \\
\text { Software } \\
\text { (US\$m) }\end{array}$ & $\begin{array}{l}\text { Piracy } \\
\text { Rate } \\
(\%)\end{array}$ \\
\hline Australia & 27 & 4 & 3.8 & 4 & na & na \\
\hline China & 124 & 100 & 300.0 & 54 & 1286.0 & 99 \\
\hline Hong Kong & 10 & 4 & 5.0 & 13 & 112.2 & 74 \\
\hline India & 58 & 99 & 10.0 & 30 & 25.8 & 76 \\
\hline Indonesia & 15 & 98 & 2.0 & 9 & 82.6 & 80 \\
\hline Japan & 108 & 10 & na & na & na & na \\
\hline Malaysia & 42 & 85 & 19.0 & 16 & 48.0 & 71 \\
\hline Philippines & 26 & 90 & 3.0 & 22 & 28.0 & 90 \\
\hline Singapore & 18 & 2 & 2.4 & 9 & 44.0 & 42 \\
\hline S. Korea & 17 & 15 & 6.0 & 18 & 13.6 & 66 \\
\hline Taiwan & 29 & 15 & 5.0 & 13 & 105.4 & 69 \\
\hline Thailand & 29 & 65 & 5.0 & 13 & 73.3 & 80 \\
\hline Vietnam & 5 & 100 & na & na & 15.0 & 99 \\
\hline
\end{tabular}

Source: International Intellectual Property Alliance, web page press release, 1996, http://www.iipa.com/thml/body_piracy_losses.html. 
TABLE 3 (Part I)

\section{US-CHINA TRADE IN PATENT, TRADE MARK AND COPYRIGHT GOODS: 1987, 1994, 2000}

Patent Goods

(SITC)
US US China China

Year Exports Import Exports Imports
US

US

Exports Imports to China from China

\begin{tabular}{lrrrrrrr}
\hline Alcohols, phenols, etc. & 1987 & 798 & 660 & 75 & 165 & 12 & 12 \\
SITC 512 & 1994 & 1,451 & 1,392 & 208 & 307 & 18 & 17 \\
& 2000 & 1,928 & 1,840 & 260 & 1,604 & 85 & 30 \\
\hline Medical/Pharmaceutical & 1987 & 3,348 & 2,498 & 421 & 240 & 24 & 34 \\
Products & 1994 & 3,805 & 2,531 & 925 & 217 & 15 & 147 \\
SITC 541 & 2000 & 5,850 & 4,924 & 1,515 & 255 & 38 & 397 \\
\hline Polymerization Products, etc & 1987 & 2,949 & 1,281 & 54 & 1,223 & 232 & 3 \\
SITC 583 & 1994 & 77 & 129 & 323 & 1,024 & 0 & 0 \\
& 2000 & 178 & 334 & 7 & 19 & 1 & 2 \\
\hline Other Machinery for Special & 1987 & 2,994 & 3,761 & 62 & 2,762 & 128 & 5 \\
Industries & 1994 & 6,450 & 5,316 & 306 & 7,002 & 327 & 34 \\
SITC 728 & 2000 & 15,300 & 9,666 & 552 & 5,877 & 359 & 128 \\
\hline Metalworking Machinery & 1987 & 1,639 & 3,092 & 99 & 979 & 74 & 7 \\
SITC 73 & 1994 & 3,899 & 4,756 & 327 & 3,125 & 296 & 67 \\
& 2000 & 6,167 & 7,970 & 720 & 2,999 & 204 & 139 \\
\hline Office Machines & 1987 & 457 & 2,475 & 95 & 110 & 2 & 5 \\
SITC 751 & 1994 & 799 & 3,939 & 554 & 108 & 8 & 302 \\
& 2000 & 996 & 3,007 & 1,550 & 360 & 15 & 885 \\
\hline Automatic Data-Processing & 1987 & 9,643 & 7,314 & 20 & 462 & 148 & 0 \\
Equipment & 1994 & 17,726 & 30,615 & 987 & 832 & 159 & 735 \\
SITC 752 & 2000 & 24,803 & 57,065 & 10,994 & 4,516 & 759 & 6,540 \\
\hline Electro-Medical \& X-ray & 1987 & 1,519 & 1,452 & 2 & 201 & 26 & 0 \\
Equipment & 1994 & 2,716 & 1,917 & 24 & 226 & 57 & 8 \\
SITC 774 & 2000 & 4,406 & 3,253 & 113 & 683 & 149 & 50 \\
\hline Electronic Microcircuits & 1987 & 1,623 & 6,083 & 1 & 74 & 1 & 0 \\
SITC 7764 & 1994 & 15,820 & 23,383 & 141 & 1,544 & 13 & 29 \\
& 2000 & 38,680 & 42,021 & 2,772 & 13,300 & 506 & 461 \\
\hline Surveying, Measuring, & 1987 & 5,971 & 3,263 & 38 & 777 & 160 & 6 \\
Drawing \& Gas Control Inst. & 1994 & 11,205 & 6,036 & 273 & 1,461 & 255 & 136 \\
SITC 874 & 2000 & 21,106 & 12,883 & 902 & 2,982 & 468 & 470 \\
\hline
\end{tabular}




\section{TABLE 3 (Part II)}

\section{US-CHINA TRADE IN PATENT, TRADE MARK AND COPYRIGHT GOODS: 1987, 1994, 2000}

Trade Mark Goods

US US China China US Exports US Imports (SITC) Year Exports Imports Exports Imports to China

\begin{tabular}{lrrrrrrr}
\hline Alcoholic Beverages & 1987 & 227 & 3,554 & 41 & 11 & 0 & 11 \\
SITC 112 & 1994 & 889 & 4,211 & 208 & 308 & 1 & 8 \\
& 2000 & 1,147 & 7,820 & 123 & 155 & 2 & 10 \\
\hline Perfumery, Cosmetics, & 1987 & 335 & 546 & 25 & 5 & 0 & 1 \\
etc. & 1994 & 1,715 & 1,250 & 106 & 25 & 6 & 0 \\
SITC 553 & 2000 & 2,844 & 2,375 & 266 & 74 & 15 & 99 \\
\hline Glassware & 1987 & 180 & 857 & 40 & 17 & 0 & 19 \\
SITC 665 & 1994 & 560 & 1,229 & 174 & 69 & 2 & 49 \\
& 2000 & 865 & 2,051 & 498 & 258 & 10 & 211 \\
\hline Motor Vehicle Parts \& & 1987 & 10,925 & 14,180 & 1,434 & 1,836 & 18 & 3 \\
Accessories & 1994 & 21,591 & 20,708 & 251 & 740 & 44 & 105 \\
SITC 784 & 2000 & 30,500 & 29,219 & 1,129 & 2,128 & 124 & 482 \\
\hline Furniture and parts thereof & 1987 & 828 & 5,057 & 177 & 42 & 4 & 79 \\
SITC 821 & 1994 & 3,127 & 8,080 & 1,493 & 111 & 11 & 851 \\
& 2000 & 4,744 & 20,604 & 4,582 & 170 & 53 & 5,264 \\
\hline Travel Goods, Handbags & 1987 & 49 & 2,045 & 253 & 3 & 0 & 318 \\
SITC 831 & 1994 & 233 & 3,291 & 2,365 & 50 & 1 & 1,673 \\
& 2000 & 351 & 4,778 & 3,882 & 33 & 3 & 2,396 \\
\hline Clothing & 1987 & 1,143 & 22,116 & 5,338 & 17 & 1 & 2,192 \\
SITC 84 & 1994 & 5,464 & 38,643 & 23,731 & 622 & 8 & 6,666 \\
& 2000 & 8,173 & 67,115 & 36,071 & 1,192 & 7 & 8,924 \\
\hline Watches, Movements \& & 1987 & 93 & 1,747 & 483 & 456 & 0 & 28 \\
Cases & 1994 & 276 & 2,713 & 1,914 & 1,090 & 1 & 349 \\
SITC 885 & 2000 & 348 & 3,599 & 1,831 & 826 & 2 & 678 \\
\hline Toys, Indoor Games, etc. & 1987 & 355 & 3,976 & 886 & 620 & 0 & 736 \\
SITC 8942 & 1994 & 66 & 5,255 & 3,064 & 119 & 0 & 3,627 \\
& 2000 & 541 & 10,425 & 5,575 & 54 & 4 & 8,619 \\
\hline Copyright Goods & 1987 & 1,562 & 1,589 & 23 & 95 & 13 & 3 \\
\hline Printed Matter & 1994 & 116 & 2,329 & 139 & 248 & 0 & 80 \\
SITC 892 & 2000 & 4,778 & 3,871 & 487 & 538 & 46 & 411 \\
\hline Sound Recording Tape, & 1987 & $\mathrm{NA}$ & $\mathrm{NAA}$ & $\mathrm{NA}$ & $\mathrm{NA}$ & $\mathrm{NA}$ & $\mathrm{NA}$ \\
Discs & 1994 & 59 & 778 & 31 & 60 & 0 & 9 \\
SITC 8986 \& 8987 & 2000 & 3,636 & 1,446 & 78 & 666 & 55 & 48 \\
\hline Source: United Nations, Com & & & & & & \\
& & & & & \\
& & & &
\end{tabular}

Source: United Nations, Commodity Trade Statistics $(1987,1994)$, Series D. Data for year 2000 was obtained directly from the United Nations. 
TABLE 4 (Part I)

\section{US-CHINA TRADE IN PATENT, TRADE MARK AND COPYRIGHT GOODS: 1987, 1994, 2000}

\begin{tabular}{|c|c|c|c|c|c|}
\hline $\begin{array}{l}\text { Patent Goods } \\
\text { (SITC) }\end{array}$ & Year & $\begin{array}{l}\text { China Trade } \\
\text { (\$millions) }\end{array}$ & $\begin{array}{r}\text { US } \\
\text { RCAM } \\
\end{array}$ & $\begin{array}{r}\text { China } \\
\text { RCAM }\end{array}$ & $\begin{array}{r}\text { US RCAM } \\
\text { (China) } \\
\end{array}$ \\
\hline \multirow{3}{*}{$\begin{array}{l}\text { Alcohols, phenols, etc. } \\
\text { SITC } 512\end{array}$} & 1987 & 24 & 2.02 & 0.50 & 1.70 \\
\hline & 1994 & 35 & 1.40 & 0.65 & 4.33 \\
\hline & 2000 & 115 & 1.84 & 0.15 & 19.88 \\
\hline \multirow{3}{*}{$\begin{array}{l}\text { Medical/Pharmaceutical Prod } \\
\text { SITC } 541\end{array}$} & 1987 & 58 & 2.24 & 1.93 & 1.20 \\
\hline & 1994 & 162 & 2.02 & 4.07 & 0.42 \\
\hline & 2000 & 435 & 2.66 & 5.37 & 0.67 \\
\hline \multirow{3}{*}{$\begin{array}{l}\text { Polymerization Products, etc. } \\
\text { SITC } 583\end{array}$} & 1987 & 235 & 3.85 & 0.05 & 131.37 \\
\hline & 1994 & 0 & 0.80 & 0.30 & $--^{\mathrm{a}}$ \\
\hline & 2000 & 3 & 1.05 & 0.33 & 3.51 \\
\hline \multirow{3}{*}{$\begin{array}{l}\text { Other Machinery for Special } \\
\text { Industries } \\
\text { SITC } 728\end{array}$} & 1987 & 133 & 1.33 & 0.02 & 43.49 \\
\hline & 1994 & 361 & 1.63 & 0.04 & 39.35 \\
\hline & 2000 & 487 & 2.14 & 0.08 & 19.68 \\
\hline \multirow{3}{*}{$\begin{array}{l}\text { Metalworking Machinery } \\
\text { SITC } 73\end{array}$} & 1987 & 81 & 0.89 & 0.11 & 17.96 \\
\hline & 1994 & 363 & 1.10 & 0.10 & 18.08 \\
\hline & 2000 & 343 & 1.45 & 0.22 & 10.30 \\
\hline \multirow{3}{*}{$\begin{array}{l}\text { Office Machines } \\
\text { SITC } 751\end{array}$} & 1987 & 7 & 0.31 & 0.95 & 0.68 \\
\hline & 1994 & 310 & 0.27 & 4.90 & 0.11 \\
\hline & 2000 & 900 & 0.36 & 3.89 & 0.12 \\
\hline \multirow{3}{*}{$\begin{array}{l}\text { Automatic Data-Processing } \\
\text { Equipment/SITC } 752\end{array}$} & 1987 & 148 & 2.20 & 0.05 & $--^{a}$ \\
\hline & 1994 & 894 & 0.78 & 1.13 & 0.89 \\
\hline & 2000 & 7299 & 1.02 & 2.20 & 0.81 \\
\hline \multirow{3}{*}{$\begin{array}{l}\text { Electro-Medical \& X-ray } \\
\text { Equipment/SITC } 774\end{array}$} & 1987 & 26 & 1.75 & 0.01 & $-{ }^{\mathrm{a}}$ \\
\hline & 1994 & 65 & 1.90 & 0.10 & 29.15 \\
\hline & 2000 & 199 & 2.50 & 0.15 & 20.91 \\
\hline \multirow{3}{*}{$\begin{array}{l}\text { Electronic Microcircuits } \\
\text { SITC } 7764\end{array}$} & 1987 & 1 & 0.45 & 0.01 & $--^{a}$ \\
\hline & 1994 & 42 & 0.91 & 0.09 & 1.83 \\
\hline & 2000 & 967 & 1.20 & 0.19 & 7.70 \\
\hline \multirow{3}{*}{$\begin{array}{l}\text { Surveying, Measuring, } \\
\text { Drawing \& Gas Control Inst. } \\
\text { SITC } 874\end{array}$} & 1987 & 166 & 3.06 & 0.05 & 45.30 \\
\hline & 1994 & 391 & 2.50 & 0.18 & 7.67 \\
\hline & 2000 & 938 & 3.28 & 0.27 & 6.99 \\
\hline
\end{tabular}

Note: ${ }^{a}$ Zero U.S. imports from China in indicated sector. 
TABLE 4 (Part II)

US-CHINA TRADE IN PATENT, TRADE MARK AND COPYRIGHT GOODS: 1987, 1994, 2000

\begin{tabular}{|c|c|c|c|c|c|}
\hline $\begin{array}{l}\text { Trade Mark Goods } \\
\text { (SITC) }\end{array}$ & Year & $\begin{array}{r}\text { US-China Trade } \\
\text { (millions) }\end{array}$ & $\begin{array}{r}\text { US } \\
\text { RCAM }\end{array}$ & $\begin{array}{r}\text { China } \\
\text { RCAM }\end{array}$ & $\begin{array}{r}\text { US RCAM } \\
\text { (China) }\end{array}$ \\
\hline Alocholic Beverages & 1987 & 11 & 0.11 & 4.09 & 0.00 \\
\hline \multirow[t]{2}{*}{ SITC 112} & 1994 & 9 & 0.28 & 0.65 & 0.51 \\
\hline & 2000 & 12 & 0.26 & 0.72 & 1.40 \\
\hline Perfumery, Cosmetics, etc. & 1987 & 1 & 1.02 & 5.49 & 0.00 \\
\hline \multirow{2}{*}{ SITC 553} & 1994 & 6 & 1.84 & 4.05 & $--^{\mathrm{a}}$ \\
\hline & 2000 & 114 & 2.12 & 3.25 & 1.06 \\
\hline Glassware & 1987 & 19 & 0.35 & 2.58 & 0.00 \\
\hline \multirow[t]{2}{*}{ SITC 665} & 1994 & 51 & 0.61 & 2.41 & 0.17 \\
\hline & 2000 & 221 & 0.74 & 1.74 & 0.33 \\
\hline Motor Vehicle Parts \& & 1987 & 21 & 1.29 & 0.86 & 10.19 \\
\hline Accessories & 1994 & 149 & 1.40 & 0.32 & 1.71 \\
\hline SITC 784 & 2000 & 606 & 1.84 & 0.48 & 1.81 \\
\hline Furniture and parts thereof & 1987 & 83 & 0.27 & 4.63 & 0.09 \\
\hline \multirow[t]{2}{*}{ SITC 821} & 1994 & 862 & 0.52 & 12.85 & 0.05 \\
\hline & 2000 & 5317 & 0.41 & 24.35 & 0.07 \\
\hline Travel Goods, Handbags & 1987 & 318 & 0.04 & 92.61 & 0.00 \\
\hline \multirow[t]{2}{*}{ SITC 831} & 1994 & 1674 & 0.10 & 45.20 & 0.00 \\
\hline & 2000 & 2399 & 0.13 & 106.26 & 0.01 \\
\hline Clothing & 1987 & 2193 & 0.09 & 344.82 & 0.00 \\
\hline \multirow[t]{2}{*}{ SITC 84} & 1994 & 6674 & 0.19 & 36.46 & 0.00 \\
\hline & 2000 & 8931 & 0.22 & 27.33 & 0.01 \\
\hline Watches, Movements \& & 1987 & 28 & 0.09 & 1.16 & 0.00 \\
\hline Cases & 1994 & 350 & 0.14 & 1.68 & 0.01 \\
\hline SITC 885 & 2000 & 680 & 0.17 & 2.00 & 0.02 \\
\hline Toys, Indoor Games, etc. & 1987 & 736 & 0.15 & 1.57 & 0.00 \\
\hline \multirow[t]{2}{*}{ SITC 8942} & 1994 & 3627 & 0.02 & 24.61 & 0.00 \\
\hline & 2000 & 8623 & 0.09 & 93.25 & 0.00 \\
\hline \multicolumn{6}{|l|}{ Copyright Goods } \\
\hline Printed Matter & 1987 & 16 & 1.64 & 0.27 & 7.36 \\
\hline \multirow{2}{*}{ SITC 892} & 1994 & 80 & 0.07 & 0.54 & 0.00 \\
\hline & 2000 & 457 & 2.18 & 0.82 & 0.79 \\
\hline Sound Recording Tape, & 1987 & na & na & na & \\
\hline Discs & 1994 & 9 & 0.10 & 0.49 & 0.00 \\
\hline SITC $8986 \& 8987$ & 2000 & 103 & 4.44 & 0.11 & 8.04 \\
\hline
\end{tabular}

Source: Same as Table 3.

Note: ${ }^{a}$ Zero U.S. imports from China in indicated sector.

${ }^{\mathrm{b}}$ Zero Chinese imports in indicated sector. 
TABLE 5

U.S. TRADE DEFICITS WITH CHINA AND THE WORLD: 1980-1999

\begin{tabular}{|c|c|c|c|c|c|}
\hline Year & $\begin{array}{l}\text { US Global } \\
\text { Trade Deficit }\end{array}$ & $\begin{array}{l}\text { US Exports } \\
\text { to China }\end{array}$ & $\begin{array}{l}\text { US Imports } \\
\text { from China }\end{array}$ & $\begin{array}{l}\text { US Merchandise } \\
\text { Trade Deficit } \\
\text { with China }\end{array}$ & $\begin{array}{l}\text { Adjusted US } \\
\text { Trade Deficit } \\
\text { With China } \\
\end{array}$ \\
\hline 1978 & $-33,927$ & 821 & 324 & 497 & --- \\
\hline 1979 & $-27,568$ & 1,724 & 592 & 1,132 & --- \\
\hline 1980 & $-25,500$ & 3,754 & 1,058 & 2,696 & --- \\
\hline 1981 & $-28,023$ & 3,603 & 1,865 & 1,737 & --- \\
\hline 1982 & $-36,485$ & 2,912 & 2,284 & 628 & --- \\
\hline 1983 & $-67,102$ & 2,176 & 2,244 & -68 & --- \\
\hline 1984 & $-112,492$ & 3,004 & 3,065 & -61 & --- \\
\hline 1985 & $-122,173$ & 3,852 & 3,862 & -10 & --- \\
\hline 1986 & $-145,081$ & 3,105 & 4,771 & $-1,666$ & --- \\
\hline 1987 & $-159,557$ & 3,488 & 6,294 & $-2,805$ & --- \\
\hline 1988 & $-126,959$ & 5,023 & 8,512 & $-3,489$ & --- \\
\hline 1989 & $-115,245$ & 5,807 & 11,989 & $-6,181$ & $-3,400$ \\
\hline 1990 & $-109,030$ & 4,807 & 15,224 & $-10,417$ & $-7,200$ \\
\hline 1991 & $-74,068$ & 6,238 & 18,855 & $-12,617$ & $-8,500$ \\
\hline 1992 & $-96,106$ & 7,339 & 25,514 & $-18,176$ & $-12,600$ \\
\hline 1993 & $-132,609$ & 8,619 & 31,425 & $-22,806$ & $-15,500$ \\
\hline 1994 & $-166,192$ & 9,178 & 38,573 & $-29,395$ & $-21,100$ \\
\hline 1995 & $-173,560$ & 11,748 & 45,555 & $-33,807$ & $-24,000$ \\
\hline 1996 & $-191,270$ & 11,978 & 51,495 & $-39,520$ & --- \\
\hline 1997 & $-196,665$ & 12,805 & 62,552 & $-49,747$ & --- \\
\hline 1998 & $-246,854$ & 14,258 & 71,156 & $-56,898$ & --- \\
\hline 1999 & $-345,559$ & 13,118 & 81,786 & $-68,668$ & --- \\
\hline
\end{tabular}

Sources: Overall U.S. Trade Deficit from 2001 Economic Report of the President, Table B-103; adjusted U.S. trade deficit with China from Fung and Lau (1996), Table 7; U.S. trade with China from Dept. of Commerce, ntdb, 1990-99; Harry Harding (1992) for U.S. trade with China, 1978-1990. 
TABLE 6

\section{CORRELATION BETWEEN IPR-INTENSIVE PRODUCTION AND ELECTORAL VOTES}

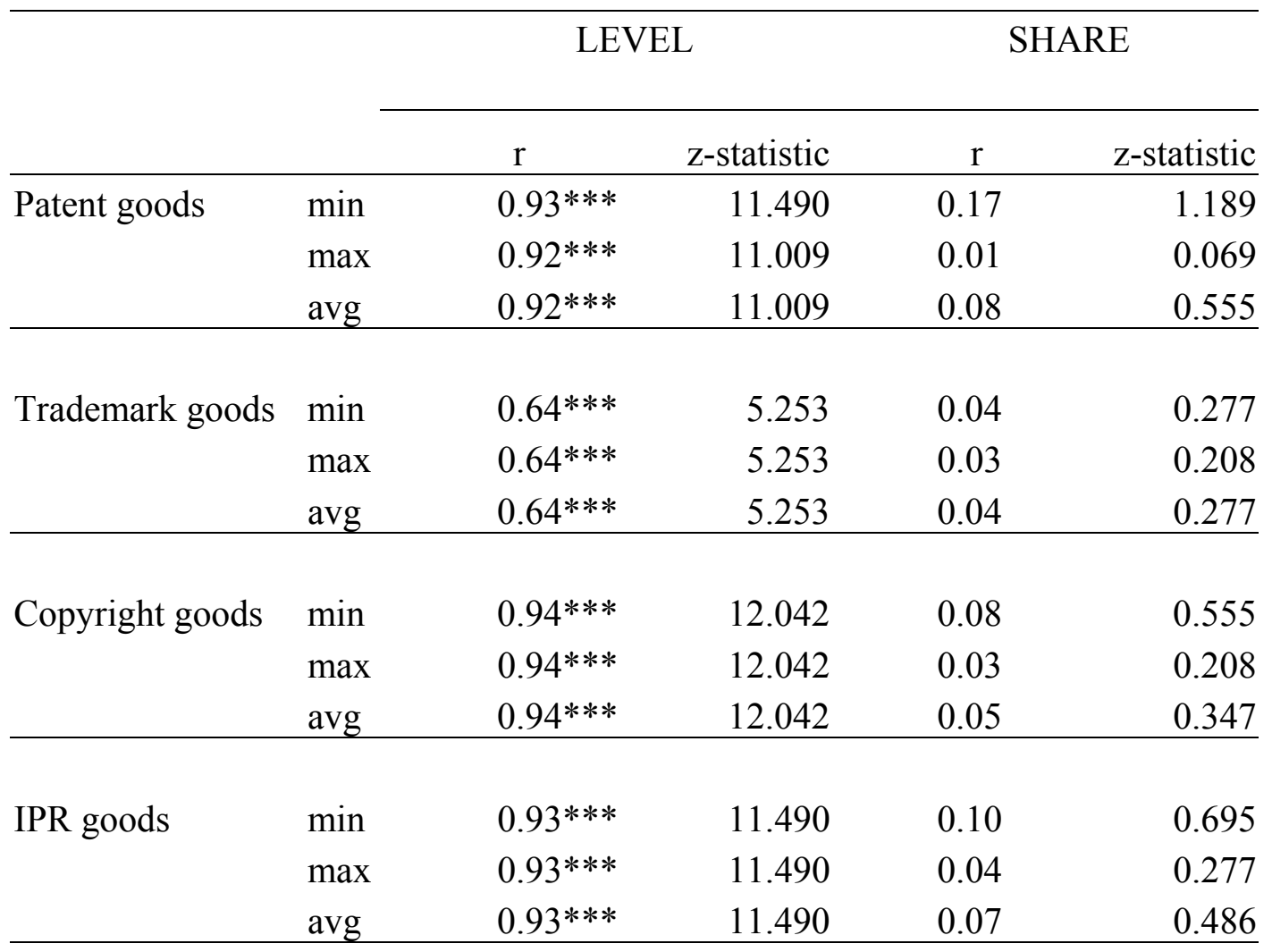

Note: $* * *$ statistically significant at the 1 percent level 